\title{
Media and information literacy is lifelong education component
}

\author{
Svetlana Gudilina ${ }^{1, *}$ \\ ${ }^{1}$ ISED RAE, Centre of Lifelong Education, 105062, Moscow, Russia
}

\begin{abstract}
Mass communications play an important role in lifelong education. Therefore there is a need for formation of media and information literacy at students. The article also describes the features of the European approach to media and information literacy. The necessity of introduction of integrated media education in formal education for the development of metasubject skills needed for further learning and professional training throughout life. The following priority tasks of media education which are identified through experimental research are under discussion: formation of critical thinking, development of information security skills, ethics, etiquette, morality and responsibility. To implement an integrated media education, the strategic actions are: inclusion of the concept of "media education" or "media and information literacy" in the regulations for the formal education, a need to create media education environment as a part of education environment of education institutions, including media education training of students in activity of pedagogical institutions.
\end{abstract}

A system of lifelong education is becoming popular in a rapidly changing world. The concept of "lifelong learning" in a pedagogical literature is interpreted in different ways of expression: education throughout life, adult education, continuing education, continuing professional education. We will consider the first way, which was indicated in the Russian and European educational policy.

Europe developed a strategy for lifelong learning as comprehensive learning activities undertaken on an ongoing basis with the aim to improve knowledge, skills and professional competence [1]. And the State program of the Russian Federation "Development of Education in the year 2013-2020" defines the tasks of lifelong education: formation of flexible, accountable to the public system of lifelong education, developing human capital, ensuring current and future needs of the socio-economic development of the Russian Federation, as well as ensuring an effective system for socialization and self-realization of young people, youth development potential. Implementation of tasks provides support for social activity of young people [2]. Thus, it can be argued that the concept of lifelong education solves the problems, which are aimed at preparation of a man capable to obtain periodically new knowledge in the process of education or vocational training. Skills of self-training and self-education become significant in realization of cognitive interests, in disclosure of potential and abilities of the person for achievement of objectives of training.

Purposeful independent cognitive activities largely contribute to information technology and mass communication, which form the education environment at different levels of education - formal, informal and non-formal. It becomes necessary for any student to develop information skills training purposes: to find information from different sources; identify reliable sources; analyze and critically refers to the information received; work with verbal, visual, audio, audio-visual texts; organize, classify and process information; develop information and communication technologies and use technical means in the educational activity.

Refracting information skills in the media, which have their own characteristics and is actively gaining educational space, it's necessary to add a number of skills: to understand the language of mass media, for what purpose and for whom are media texts, which values are transferred to audience, to understand the subtext of information, to interpret the messages and draw conclusions, to be aware of the consequences of the impact on the psyche of these texts, to master the methods of communication on the basis of verbal and non-verbal forms of communication with the help of technical means. A distinctive feature of these skills can be called conscious interaction with the communication medium that is oversaturated with information. Versatility, interactivity and accessibility of technology make them attractive and comfortable to users. Each successive generation of technology becomes more and more comfortable to learn and to be used. Therefore, we can observe how media environment is constantly being transformed with arrival of new technologies. Many of processes associated with socialization and other education processes, not related to traditional educational environment. However, network technology, and

\footnotetext{
Corresponding author: gudilinas@mail.ru
} 
especially social media, continue to have a major impact on the education and professional activities.

Association of the listed above groups of abilities integrates media and information education. Media and information literacy is written as one of the strategic priorities of UNESCO's Intergovernmental Program "Information for All". "Media and Information Literacy is a combination of knowledge, attitudes and skills that allow to get access to information and knowledge, to analyze, evaluate, use, create, and distribute them with maximize productivity in accordance with legal and ethical standards and in compliance with the human rights. Media and information literate person can use a variety of sources and channels of information in the personal, professional and social life. He knows when and what information is required and what, where and how it can be obtained. He knows who and for what purpose created and distributes this information, he has an idea about the roles and responsibilities of the media functions, memory institutions and other information providers. He can analyze the information, messages, ideas and principles, broadcast media and other content producers, to determine the accuracy of the received and generated information on a number of public, personal and contextual criteria. Media and information literacy goes beyond the ownership of communication and information technology and includes critical thinking skills, comprehension, and interpretation of information in different areas of professional, educational and social activities. Media and information literacy implies the ability to work with all sources of information (oral, written, electronic and analog / digital) as well as with all kinds and types of information resources [3]."

While analyzing the interpretation put forward by "media and information literacy", one can understand what huge didactic formation is revealing. Semiotic, cognitive and activity-centered approaches to the disclosure of the intellectual capacities needed for life in the information space were used.

This raises another question - the question of adaptation "of media and information literacy" to the Russian mentality. Consider a training program developed by UNESCO educators of media and information literacy. The program includes training description, system competence and description of basic and additional modules. Material is recommended to process and attach to global, regional and national strategies.

This list of terms (Media literacy, information literacy, digital literacy, library literacy, computer literacy, Internet literacy, cinema literacy, television literacy, literacy in the field of advertising and others) almost collected all the areas of information services and established competence to complement the existing training system teachers. Features of authors' approach to the solution of education and methodical tasks consists in association of various levels and forms of education. Therefore, the material is designed for teachers in primary and secondary schools, colleges, universities and others.
Strategic principles put forward the motto of Declaration of Human Rights on the right to freedom of opinion and expression. Competencies of media and information literacy equip teachers with extensive knowledge about the functioning of information services and have become an important tool for intercultural dialogue, mutual understanding of the peoples and their cultures.

Stimulation of democratic and civil processes can only be welcomed, but to be limited only to intellectual activity - it means to forget about emotional and moral, ethical culture, about those traditional values which are the cornerstone of knowledge of the world. Professor and media teacher A. V. Fedorov correctly expresses concern about refusal of communication of media and information literacy with art education [4]. Substantive discussion of the movie and any visual texts is not possible when it's done only at the cognitive level. Media criticism should be based on aesthetic principles that enable and combines sensual and rational, and conceptual thinking. Creativity is presented at all stages of media production. Analysis of the psychological characteristics of the images, art techniques reveal the author's design logic. The most complete disclosure of the meaning and importance of the media product helps to adequate perception and evaluation. It can be concluded that the Russian educational policy should expand media and information literacy and integrate art education.

Recent changes in the information environment is largely due to content and resources. There is a reduction in verbal information, it is replaced by the audio-visual - video clips, music, graphics. If earlier texts were created by competent experts, then now all Internet users publish and distribute media texts. Availability of information communication technologies creates security problems. The right to freedom of expression sometimes denies all ethical and legal standards. Negative behavior in the Internet environment erodes the standards of conduct that are transported in real life. It becomes clear that the moral and ethical norms do not work. Global network, on the one hand, is developing to make our lives comfortable, on the other - creates serious problems.

The prophetical statement of Marshall Maklyuen comes true: "First we shape technology, and then they shape us." Transformations take place in our life. Mass media create an environment that consists of a complex world of images. Mounting of media created images configures the audience and to a new way of thinking. The American philosopher Alvin Toffler introduced even a new concept of "clip culture". The video is a short film of a mosaic of images. Young people "feel not bad under bombing of blitz: the one and a half minute clip with news, the semi-minute commercial, a fragment of a song or the poem, heading, an animated cartoon, a collage, a piece of news, computer graphics. Being a voracious reader of cheap books and specialized magazines, they gulp swallow vast amounts of information. But they are also watching closely how the new concepts or metaphors are collected and organized into a kind of whole pieces of data 
information. Instead of trying to cram the new modular structure of data in the standard ... they are learning to create their own "band" of ideas from the broken material to bring down upon them the new media".

With the invention of the Internet information-rich environment is constantly increasing. Development of clip thinking is a defensive reaction to information overload that we see and hear on a daily basis. Not surprisingly, that the minds of children and adolescents adapt to the new world. You can watch as the teens with clip thinking can listen to music at the same time, social networking, and while doing homework. In clip thinking the skill to quickly switch from one object to another is developing, the world is transforming into a little unrelated fragments. The feature of such thinking is manifested in large data processing speed and preference non-textual, pictorial information. Unfortunately, such people are no longer capable of prolonged activity of something one, for example, reading, school work and so forth. The psychological and pedagogical studies for the development of attention, memory and thinking is recommended in the traditional form to include more jobs of not logical development but creative thinking (hemispheric or intuitive nature) - the development of feelings, emotions, movement, fine motor. It's interesting to know that lessons in visual arts and technology will help adequate development of the person.

Forecasts for improving network technologies affect the philosophical, political, economic, legal questions. Only one correct way can be in the most unpredictable social and cultural situation - it is training the young generation, the ability to adequately communicate with mass communication. It is necessary to clarify what kind of preparation is involved. When we talk about literacy, it means that a competent person has necessary skills to solve everyday problems. The modern interpretation of functional literacy, in addition to linguistic, legal, civil, financial, environmental, professional skills, including media and information skills. It's qiete simple to be able to create and distribute media texts with the modern possibilities of technology. An educated person can argue, have opinion, possess knowledge of humanity. Therefore, the younger generation should get a good education. Media education acts as a component of cultural training of students in accordance with the social order of modern civilization. On logic "literacy" has to be replaced with "education". The English-language translation of the concept of "literacy" with a narrower meaning than "education" should be replaced. But the interpretation of "media and information literacy" is interpreted quite widely in the content. Therefore, we can say that the concept of "media education" or "information education" are treated as synonyms of "media and information literacy."

There is another important issue for the Russian practice on the issue of the introduction of media education in formal education. Often a media education is understood as the special training of journalists, cameramen and other experts in the field of media. But we're talking about a different direction, which tells about the work of these professionals, the work of the media, a critical attitude towards the information received from various sources, as well as how to create the media on the basis of received knowledge. This integrated media education (integration of media education with the natural sciences and the humanities), which can provide a good general cultural training of pupils and students, without requiring additional training hours. At the same time material of training courses gives a factual basis for media education, and results of media educational activity become metasubject that is one of the main requirements of implementation of the Federal state education standards $[5,6]$.

Foreign experience shows that media education is included in the base system of schools with grades from 1 to 12 in Canada, Australia, Hungary, the Czech Republic, Slovakia and other countries. And in Russia we have experimental experience at the different levels of education and training (kindergarten-school-higher education institution). It is shown that if at the level of preschool educational institution propaedeutic media educational problems are solved, then already at school when critical thinking of a pupil begins to develop, tasks are set to demonstrate possibilities of media technologies. Methodical principles of students' media education training as future teachers were tested at the level of a pedagogical higher institution.

Of course, there are positive promotion at the state level. Media educational individual assignments are included in educational standards. There is a financing of hardware for education institutions, information and education environment of education institutions, electronic resources, courses on professional development of teachers But this is not enough. To implement integrated media education, the priority actions are: inclusion of the concept of "media education" or "media and information literacy" in the regulations, formation of media education environment as part of education environment of an education institution and consideration of preparation of students of pedagogical universities and teachers.

The primary goals of media education are: formation of critical thinking, development of information security skills, ethics, etiquette, morality and responsibility. This raises a number of issues that require a separate comprehensive study of physiologists, psychologists and educators concerning the perception of media texts, working with computer, its impact on the physical, the mental state of a person, personal development. Special attention requires study of social media. Results of the international social and psychological researches show ambiguous influence of social networks on a psychological state of a person and development of a system of judgments.

Transfer to new generations of scientific knowledge and values are considered by humanitarian education. Humanization helps to develop the identity of a man with a broad outlook. Forming their own world, a common culture, including media education, spiritual and moral, legal, communicative, aesthetic, economic and environmental - these are aspects of education on 
the basis of their own meanings, which are necessary for everyone.

\section{References}

1. Memorandum nepreryvnogo obrazovaniya Evropeiskogo soyuza. Available online: URL http://www.znanie.org/docs/memorandum.html (accessed on 03.04.15) [In Rus]

2. Gosudarstvennaya programma $R F \quad$ «Razvitie obrazovaniya na 2013-2020 gody». Available online: URL http://минобрнауки.pф/3409 (accessed on 09.0116) [In Rus]

3. E. I Kuz'min, and A. V. Parshakova, Media- $i$ informatsionnaya gramotnost' $v$ obshchestvakh znaniya. Available online: URL http://www.rusameeduforum. com $/$ content/ru/?task $=$ art\&article $=1$ $001025 \&$ iid $=18$ (accessed on 13.02.16) [In Rus]

4. A.V. Fedorov, Distantsionnoe i virtual'noe obuchenie, 10, 72, (2013) [In Rus]

5. L.S. Zaznobina, Standarty i monitoring $\mathrm{v}$ obrazovanii, 3 (1998) [In Rus]

6. S.I. Gudilina, Rossiisko-amerikanskii forum obrazovaniya: elektronnyi zhurnal, 6. Available online: URL http://www.rusameeduforum. $\operatorname{com} /$ content/ru/?task $=$ art\&article $=1$ 001025\&iid $=18$ (accessed on 05.09.2015) [In Rus] 